\title{
Relationship between filter cigarettes smoking habits with the appearance of smoker's melanosis (Observation of smoking duration and the amount of cigarettes consumption)
}

\author{
Rizal Rizky Akbar*, Sunardhi Widyaputra*, Silvi Kintawati* \\ Department of Oral Biology Faculty of Dentistry Padjadjaran University
}

\begin{abstract}
Introduction: Smoking is one of bad habits that are difficult to abandon. Cigarettes contain more than 59 known carcinogenic substances. Cigarettes also contain some metal components and free radicals. Cigarettes consist of several types, one of which is cigarettes filter, which is the most frequently consumed cigarettes. One of the adverse effects of cigarette smoker's melanosis is a pigmentation disorder that appears in oral cavity. The study aims to look at the relationship between smoking habits of filter's smoker with appearance of smoker's melanosis. Methods: This was a descriptive analytic with chi-square test to analyze the relationship between smoking in filter smokers with appearance of smoker's melanosis. The samples were 90 students of the Faculty of Geology University of Padjadjaran. The smokers who have the criteria of the sample are examined to see the oral condition whether there is a melanosis lesion or not. Results: The result showed an association between smoking habit in filter smokers with the onset of smokers melanosis that observe through the duration of smoking and the amount of cigarettes consumption. Conclusion: There is a relationship between smoking habits in filter smokers and the onset of smoker's melanosis in terms of smoking duration and the number of cigarettes consumed.
\end{abstract}

Keywords: Cigarettes, Nicotine, Smoker's Melanosis

\section{INTRODUCTION}

Smoking is not something new as the tobacco plants have started to be planted even since 600 BC. In 1492, the tobacco plant became popular after Columbus saw the Indians smoking tobacco in certain ceremonies as a symbol of hospitality. Since then, smoking has become very popular until now. ${ }^{1}$ Smoking has become a part of society, and is not even considered a bad habit. Cigarette smoking is the main preventable cause of premature death. Smoking contribute to disease which result in death such as heart disease (1.69 million deaths), chronic obstructive pulmonary disease (0.97 million deaths), and lung cancer (0.85 million deaths) .2 Even though multiple studies had shown the health risks of smoking, but that doesn't make it disappears as most smokers seemed not to care much about the results of the study. In 2008, Indonesia had been established as the third largest country as a cigarette user by the World Health Organization (WHO).

More than 60 million people in Indonesia experience addictions and deaths from cigarette consumption with a record of more than 400 thousand deaths per year. Based on data from the ASEAN Tobacco Control Report Card in 2007, the number of smokers in ASEAN had reached 124,691 
million People while Indonesia accounted for the largest smokers, with 57,563 million people (46.16\%). Indonesia also ranks in the highest consumption of cigarettes, reaching 240 billion cigarettes or equivalent to 658 million cigarettes per day, which means apparently Rp 330 billion were spent by Indonesian smokers every day.

Cigarettes contain more than 4,000 kinds of chemicals with more than 59 known to be carcinogenic substances. ${ }^{2}$ Cigarettes contain several metal components and free radicals. Cigarettes also contain tar and nicotine. Tar is one of the carcinogenic substances found in cigarettes, while nicotine is an addictive substance that causes dependency or addiction. ${ }^{3}$ According to the Health Research and Development Agency in 2007, among all the types of cigarettes, filters was most favor by Indonesian. Smokers believe that the use of filters can reduce the negative effects of smoking. ${ }^{4}$ In fact, various tests in the laboratory show that filters only reduce nicotine levels between $25 \%-50 \%$, while the rest enters the body. Filters cigarettes indeed filter tar from the tobacco, but many of the rest are translucent in the bloodstream. Smokers will not be protected

Tabel 1. Distribusi frekuensi lama merokok

\begin{tabular}{ccc}
\hline Kriteria & Frekuensi & Persen \\
\hline$<1$ tahun & 30 & 33,3 \\
$1-5$ tahun & 30 & 33,3 \\
$>5$ tahun & 30 & 33,3 \\
\hline Total & 90 & 100,0 \\
\hline
\end{tabular}

Tabel 2. Distribusi frekuensi smoker's melanosis

\begin{tabular}{ccc}
\hline Kriteria & Frekuensi & Persen \\
\hline Ada & 58 & 64,4 \\
Tidak Ada & 32 & 35,6 \\
\hline Total & 90 & 100,0 \\
\hline
\end{tabular}

from the dangers of cigarettes unless all tar is removed from cigarettes. ${ }^{4}$ All the chemical content contained in cigarettes is very dangerous and can have a direct effect on the oral cavity. ${ }^{5}$

Oral cavity is the area most easily exposed to adverse effects due to smoking. Continuity stimulation of cigarette smoke can cause damaging effect towards oral mucosa, one of which is smoker's melanosis pigmentation. ${ }^{6}$ Smoker's melanosis is hyperpigmentation of the oral mucosa. This disorder is directly related to smoking habits regarding the length of smoking and the number of cigarettes consumed, this abnormality is usually found in the mandibular fixed gingiva and in the interdental papillae in active smokers. The prevalence of smokers with smoker's melanosis is $25-31 \% .{ }^{7}$ Smoker's melanosis is a benign disorder in the oral cavity which does not require treatment, however the lesion form on the gingiva will greatly disrupt the aesthetics. ${ }^{6,8}$

The data had shown a strong relationship between smoking and Smoker's melanosis. In addition, the assumption of the use of filters on cigarettes can reduce the adverse effects of smoking also attached interests of researchers. Based on the facts that have been mentioned, the researchers intend to conduct research on the relationship between filter smokers with the incidence of smoker's melanosis in terms of the duration of smoking and the number of cigarettes consumed. The purpose of this study was to

Tabel 3. distribusi frekuensi jumlah batang rokok

\begin{tabular}{ccc}
\hline Kriteria & Frekuensi & Persen \\
\hline 1-10 batang & 30 & 33,3 \\
11-20 batang & 30 & 33,3 \\
>20 batang & 30 & 33,3 \\
\hline Total & 90 & 100,0 \\
\hline
\end{tabular}

Tabel 4. Hubungan lama merokok dengan smoker's melanosis

\begin{tabular}{|c|c|c|c|c|c|c|c|c|}
\hline \multirow{3}{*}{ Lama merokok } & \multicolumn{4}{|c|}{ Smoker's Melanosis } & \multirow{3}{*}{ Total } & \multirow{3}{*}{$\%$} & \multirow{3}{*}{ Chi-square } & \multirow{3}{*}{ P- Value } \\
\hline & \multicolumn{2}{|c|}{ Ada } & \multicolumn{2}{|c|}{ Tidak Ada } & & & & \\
\hline & Frekuensi & PPersen & Frekuensi & Persen & & & & \\
\hline$<1$ tahun & 8 & 26,67 & 22 & 73,33 & 330 & 100,00 & & \\
\hline 1-5 tahun & 24 & 80,00 & 6 & 20,00 & 330 & 100,00 & 210 & ח \\
\hline$>5$ tahun & 26 & 86,67 & 4 & 13,33 & 330 & 100,00 & 20.317 & 0,000 \\
\hline Total & 32 & 193,33 & 58 & 106,67 & 990 & 300,00 & & \\
\hline
\end{tabular}


determine the relationship between smoking habits in filter smokers with the occurrence of smoker's melanosis in terms of smoking duration and the number of cigarettes consumed.

\section{METHODS}

This research was conducted in descriptive analytic method. This research was conducted on 90 active smokers who met the criteria by observing their oral condition.

The study population was all students in the Faculty of Geological Engineering, \{Unversitas Padjadjaran, Bandung) from year 2006-2011. Based on preliminary observations from researchers, this faculty is one of several faculties of Unversitas Padjadjaran that has a relatively large number of smokers. In addition, the number of male in this faculty is relatively higher compared to the number of female, which is in accordance with the criteria of set. Male students in age of 1823 years with a history of smoking were taken as sample in this study. The number of samples is calculated using a qualitative data formula.After conducting research on the relationship between smoking duration and the number of cigarettes consumed with smoker's melanosis, the data are presented in tabular form.

\section{RESULTS}

Tabel1 menunjukkan peneliti mengambil jumlah responden lama merokok $<1$ tahun sebanyak 30 orang $(33,33 \%), 1-5$ tahun sebanyak 30 orang $(33,33 \%)$ dan $>5$ tahun sebanyak 30 orang $(33,33 \%)$. Hasil penelitian menunjukkan terdapat 56 orang $(62,2 \%)$ yang mempunyai smoker's melanosis dan terdapat 34 orang $(37,8 \%)$ yang tidak mempunyai smoker's melanosis. (tabel 2)

Hasil penelitian (tabel 3) menunjukkan responden yang merokok dengan jumlah 1-10 batang rokok sebanyak 30 orang (33,33\%), 11-20 batang rokok sebanyak 30 orang $(33,33 \%)$, dan $>20$ batang rokok sebanyak 30 orang $(33,33 \%)$.

Perhitungan statistik uji Chi-square sebesar 6.901 dan $P$-value $=0,032$, oleh karena nilai $\mathrm{P}$-value lebih kecil dibandingkan $5 \%(0,032<0,05)$ maka terdapat hubungan yang bermakna antara jumlah rokok yang dikonsumsi dengan smoker's melanosis.

\section{DISCUSSION}

Based on the research results, there is a relationship between smoking habits in filter smokers and the occurrence of smoker's melanosis based on the amount of cigarettes consumed. The results showed that out of the 30 smokers who smoke < 1 year, 8 (22.67\%) had smoker's melanosis and 22 (73.33\%) had no smoker's melanosis; for smokers within 1-5 years, 24 smokers $(80 \%)$ had smoker's melanosis while 6 smokers (20\%) did not have smoker's melanosis; among smokers $>5$ years, 26 respondents $(86.67 \%)$ had smoker's melanosis, while 4 respondents $(13.33 \%)$ did not smoker's melanosis. Based on these data, apparently smoker's melanosis is likely to increase in people with longer smoking habits. Based on George Laskaris's theory, smoker's melanosis is influenced by the length of smoking of an individual, the longer an individual smokes, the more likely he/ she is to have smoker's melanosis. ${ }^{7}$ Similarly, the number of cigarette butts obtained shows that out of 30 smokers who smoked a total of 1-10 sticks, 13 (43.33\%) respondents had smoker's melanosis while $17(56.67 \%)$ had no smoker's melanosis; within individual that smoked for a total of 11-20 sticks, $21(70 \%)$ respondents had smoker's melanosis while 7 (30\%) had no smoker's melanosis; among respondent that smoked a total of more than 20 sticks, $22(73.33 \%)$ respondents had smoker's melanosis while 8 (26.67\%) had no smoker's melanosis. Based on these data, it appears that smoker's melanosis occurs more often in people who have a greater daily smoking habit. George Laskaris's theory also said that smoker's melanosis is influenced by the amount of cigarettes consumed. ${ }^{7}$ The more cigarettes we consume each day, the more likely we are to have smoker's melanosis. ${ }^{7}$

Smoker's melanosis is a type of pigmentation that appears quite often in people who have smoking habit. The prevalence of smoker's melanosis had reach $31 \% .^{7}$ However, smoker's melanosis is not a lesion that would lead to malignancy. ${ }^{6}$ The clinical symptoms can only be resolve by stopping smoking within a few months to several years.

This pigmentation is stimulated by various drugs such as nicotine (polycyclic mixture material) contained in a cigarette. Nicotine $(\mathrm{C} 10 \mathrm{H} 14 \mathrm{~N} 2)$ is 
a pyridine and pyrolidine ringed tertiary amine compound, is weak alkaloid so it dissolves easily in water or fat. ${ }^{9}$ These alkaloid chemical compounds have a strong and stimulant effect on the human body, so it will cause addictive effects for anyone who is addicted. Nicotine is also known to play a role in the stimulating melanin found in the skin and other tissues such as the oral mucosa. These substances will be able to disrupt the stability of the melanin pigment (melanin incontinence). ${ }^{6}$ Melanin is a type of natural pigment that is synthesized in the human body. Melanin is normally synthesized in melanocytes using the enzyme tyrosinase, the enzyme tyrosinase has an important role to convert 3, 4-dihydroxylphenylalanine (DOPA) and then into dopaquinone which will later be converted into melanin. ${ }^{10}$ Normally melanin synthesis is divided into four different stages . ${ }^{11}$ Stage 1: A vesicle is surrounded by a membrane and shows the beginning of the process of tyrosinase enzyme activity and the formation of a fine granule substance in its peripheral part. The solid strands of electrons have a neat arrangement of tyrosinase molecules in a protein matrix. ${ }^{11}$ Step 2: Vesicles (melanosomes) are oval in shape and inside they appear filaments with a distance of about $10 \mathrm{~nm}$ or latitude with the same distance. Melanin is stored in a protein matrix. ${ }^{11}$ Stage 3: Increased melanin formation makes fine structures rather difficult to see. ${ }^{11}$ Stage 4 : Mature melanin granules can be seen with a light microscope and melanin completely fills vesicles, no ultrastructures are seen. ${ }^{11}$ Mature granules are shaped The ellipse, with a length of $1 \mu \mathrm{m}$ and a diameter of $0.4 \mu \mathrm{m}$, the darkening of the skin / mucosa (tanning) is a result of the stage 2. ${ }^{11}$

Melanocytes are special cells found in the epidermis, below or between basal stratum cells. The embryological origin of melanocytes comes from neural crystalline cells. Melanocytes have a round cell body where irregular long branches begin in the epidermis. These branches are between the basal stratum cells and the stratum spinosum. ${ }^{12}$ The instability of melanin formation which can cause smoker's melanosis can be caused by two things. First, physical and chemical reactions that darken the color of melanin that has not yet emerged outside melanocytes, and stimulate it rapidly to enter keratinocytes. ${ }^{11}$ Second, the speed of melanin synthesis in melanocytes accelerates, thereby increasing the amount of melanin pigments. ${ }^{11}$

Nicotine contained in a cigarette will directly stimulate melanocytes to produce melanosomes, where the stimulation will result in an increase in melanin pigment deposits in the basal cell layer in the epithelium layer of the oral mucosa. ${ }^{13}$

The research data also shows that the use of filters does not have a significant impact towards smoking. The results of the study are in accordance with the Ernest Caldwell's theory, which state that filters on cigarettes do not have the effect of reducing substances that can damage or harm the body. The results of shows that people who have the habit of smoking filters still have a tendency to have smoker's melanosis, with a greater likelihood in filter cigarette smokers with longer smoking habits and with larger amount of cigarettes consumed daily. ${ }^{4}$ This filter only reduces $25 \%-50 \%$ of nicotine levels that causes cigarette users to experience addiction. This filter is not effective to filter out all the toxins in cigarettes. ${ }^{4}$ These substances can still irritate and cause adverse effects on the human body, one of which is smoker's melanosis. ${ }^{4}$ Smoker's melanosis abnormalities are usually influenced by the length and number of cigarettes consumed by an active smoker. As the longer and more a person smokes, the more melanin pigment deposits. The results of the study show that there is a relationship between smoking habits in filter smokers with the occurrence of smoker's melanosis in terms of smoking duration and the number of cigarettes consumed.

\section{CONCLUSION}

There is a relationship between smoking habits in filter smokers and the onset of smoker's melanosis in terms of smoking duration and the number of cigarettes consumed.

\section{REFERENCES}

1. Husaini A. Tobat merokok: rahasia \& cara empatik berhenti merokok. Pustaka Ilman: Jakarta. 2006. p. 15-17, 20-21.

2. Cahyono JB. Gaya hidup \& penyakit modern. Yogyakarta. Kanisius. 2008. p. 106. 
3. Aditama TJ. Masalah perokok dan 9. Phatologic Correlations. USA: Saunders. 129. penanggulangannya. Jakarta: Yayasan penerbitan IDI. 2003. p. 28-9.

4. Caldwell E. Berhenti merokok. Diterjemahkan dari: How You Can Stop Smoking Permanently. olehSyafruddinHasanidanSupriyantoAbdullah. Jakarta: Pustaka Populer. 2009. p. 54-6.

5. Carpenito LJ. Diagnosis keperawatan aplikasi pada praktik klinis. Jakarta. Buku kedokteran EGC. 2009. p. 523-6.

6. Greenberg MS, Glick Ml. Burket's oral medicine diagnosis \& treatment. $10^{\text {th }}$ ed. BC Decker Inc. 2003. p. 132-3.

7. Laskaris G. Color atlas of oral diseases. Athens, greece. Litsas Medical Publication. 2003. p. 78.

8. Regezi JA, Sciubba JJ, Jordan RCK. Oral Pathology: Clinical. 2003.

10. Joewana S. Gangguan mental dan perilaku akibat penggunaan zat psikoaktif: penyalahgunaan napza/narkoba. Jakarta: Buku Kedokteran EGC. 2003. p. 180-1.

11. Fawcett DW. Buku Ajar Histologi. Cetakan: 1. Jan Tambayong. Buku Kedokteran EGC. Jakarta. 2002. p. 477.

12. Junquiera LC, Carneiro J, Hill MG. Basic Histology. $11^{\text {th }}$ ed, Washington, Lange. 2005. p. 363-5.

13. Eroschenko VP. Di Fiore's Atlas Histology With Functional Correlations. USA: The Point. 2008. p. 225-6.

14. Yerger VB, Malon RE. Melanin and nicotine: A review of the literature. Nicotine \& Tobacco Research. 2006;8:487-98. 